\title{
Temperature driven development of the rice brown planthopper, Nilaparvata lugens (Stål) (Hemiptera: Delphacidae)
}

\section{JHANSILAKSHMI VATTIKUTI* ${ }^{1}$, V. SAILAJA ${ }^{2}$, Y.G. PRASAD ${ }^{4}$, G. R. KATTI ${ }^{1}$, P.M.CHIRUTKAR ${ }^{1}$, G. RAMACHANDRA RAO ${ }^{3}$, A.P. PADMAKUMARI ${ }^{1}$, CH. PADMAVATHI ${ }^{1}$ and M. PRABHAKAR ${ }^{3}$}

\author{
${ }^{1}$ ICAR-Indian Institute of Rice Research, Rajendranagar, Hyderabad-500030, India. \\ ${ }^{2}$ Forest College and Research Institute, Mulugu-, Siddipet,India. \\ ${ }^{3}$ ICAR-Central Research Institute for Dryland Agriculture, Santosh Nagar, Hyderabad-500059, India. \\ ${ }^{4}$ ICAR-Agricultural Technology Application and Research Institute, Santoshnagar, Hyderabad-500059, India. \\ *Corresponding author E-mail:jhansidrr@yahoo.co.in
}

\begin{abstract}
Temperature driven development of rice brown planthopper (BPH), Nilaparvata lugens (Stål) (Hemiptera: Delphacidae) population (biotype 4) was examined at seven constant temperatures $(15,18$, $20,25,30,32$ and $35^{\circ} \mathrm{C}$ ). Complete development of $\mathrm{BPH}$ from egg to adult was observed at constant temperatures ranging from 15 to $32^{\circ} \mathrm{C}$ with linear development observed till $30^{\circ} \mathrm{C}$. Total immature developmental duration decreased from 74.4 days at $15^{\circ} \mathrm{C}$ to 22.4 days at $30^{\circ} \mathrm{C}$. Linear and non-linear models fitted to describe developmental rates of life stages as a function of temperature, gave estimates of bioclimatic thresholds (lower, optimum and upper temperature thresholds). Thermal constants estimated from Campbell linear model for egg, nymph and cumulative immature development to adult were, 198.8, 275.5 and 473.9 degree days, respectively. Among empirical non-linear models, Lactin 2 model was selected for estimates of upper temperature threshold at $35^{\circ} \mathrm{C}$ based on higher coefficient of determination. Application of thermodynamic SSI model explained the observed nonlinear relationship of development of $\mathrm{BPH}$ life stages at temperatures higher than $30^{\circ} \mathrm{C}$. The estimated thermal constants and bioclimatic thresholds were used in developing temperature dependent phenology model based on Campbell equation. Phenology model predicted closely the occurrence of different life stages of BPH with those observed under field conditions.
\end{abstract}

Keywords: Brown planthopper; bioclimatic thresholds; phenology model; Nilaparvata lugens; temperature; thermal constant.

Brown planthopper (BPH), Nilaparvata lugens (Stål) (Hemiptera: Delphacidae) is the most destructive insect pest in the lowland irrigated rice ecosystem of tropical Asia. The insect is widely distributed and has been reported to cause large scale damage in India, Indonesia, the Philippines, Sri Lanka, Vietnam, Malaysia and Thailand (Catindig et al., 2009). In India, outbreaks of BPH have become common in recent times in several rice growing states. Due to the unpredictable nature of its infestation and the dramatic impact it causes, BPH is regarded as a pest of national importance in India. Initiation of field populations of BPH is often through migration of winged adults over long distances in many Asian countries (Rosenberg and Magor, 1987). However, in India trivial migration through dispersal over shorter distances (few $\mathrm{km}$ ) from one rice growing area to another is often responsible for starter population (Krishnaiah and Jhansilakshmi, 2012). Temperature is the most important climatic factor which directly influences development, survival and reproduction and indirectly impacts generation time and population growth rate (Fand et al., 2015). The developmental rate of an insect over a range of favourable temperatures increases linearly with increase in temperature up to certain extent. However, at temperature extremes this relationship becomes nonlinear (Wagner et al., 1984). Temperatures below the lower and above the upper temperature thresholds adversely affect enzymes involved in physiological processes related to development (Sharpe and De Michele, 1977). Previous studies from different countries reported only the optimum conditions, maximum and minimum tolerance limits of temperature and $\mathrm{RH}$ in relation to biological parameters of BPH (Lu et al., 1999) and estimation of lower developmental thresholds (Krishnaiah et al., 2005). However, there are no reports on nonlinear relationship between rate of development of the pest and higher temperatures which can be used to estimate the optimum and upper threshold 
temperatures for development. Pest phenology models provide timely management alerts and optimize pest control leading to reduction in cost of cultivation.

Hence, in the present study, the effect of different constant temperatures on development and survival of the pest was studied, two linear and three non-linear models were applied to estimate thermal constants and bioclimatic thresholds of BPH. Sharpe-Schoolfield-Ikemoto model (SSI model) was used to estimate intrinsic optimum temperature for development of BPH. Temperature dependent phenology models were developed by using the estimated thermal constants and bioclimatic thresholds which helps in the prediction of seasonal dynamics of the pest in various agroecological zones of India.

\section{MATERIALS AND METHODS}

\section{Insect culture}

Insect culture was maintained in greenhouse on 5060 days old potted plants of susceptible rice variety (TN1) in wooden cages $(70 \times 62 \times 75 \mathrm{~cm})$ at ICAR-Indian Institute of Rice Research, Hyderabad, India. Gravid females were collected with an aspirator and transferred to oviposition cages. Oviposited plants were removed daily and placed in separate cages to obtain cohorts for use in temperature experiments.

\section{Effect of constant temperatures on development and survival}

Developmental durations of pre-oviposition, egg and nymphal instars were determined at seven constant temperatures $\left(15,18,20,25,30,32\right.$ and $\left.35^{\circ} \mathrm{C}\right)$ maintained in environmental chambers (MLR 350H, SANYO Electric Company Ltd., Japan) set at constant relative humidity (60 $\pm 5 \%$ ) and photoperiod (14L:10D). Ten potted rice plants with freshly emerged females + males in 1:1 ratio covered with mylar cages were placed in the environmental chambers for oviposition. Adults were changed daily to fresh plants for three days to know the pre-oviposition period. Oviposited plants with egg cohorts placed in environmental chambers were observed daily for hatched nymphs and egg development period was calculated. Individual first instar nymphs (0-12 h old) were transferred to freshly cut rice stems kept in standing water layer at the base in test tubes closing the open end with cotton plug. Five individuals were maintained per replication with 5 replications per temperature. Each temperature experiment was repeated twice. A total of fifty nymphs were studied at each temperature $(n=50)$. Test tubes were examined daily for shed exuviae which marked the successful completion of the current instar duration. Daily mortality of nymphal instars and adults was recorded. Adult longevity and sex ratio were worked out at all temperatures.

\section{Models for parameter estimates of developmental response as a function of temperature}

Two linear and four nonlinear models were applied to estimate parameters describing the relationship of $\mathrm{BPH}$ development as a function of temperature.

\section{Linear models}

Thermal summation model (Campbell et al., 1974) is the most widely used model that explains a linear relationship between developmental rate and temperature which is expressed as

$$
r(T)=a+b T
$$

Where, $r$ is the developmental rate, that is, the reciprocal of developmental duration (D) at each temperature (T), a is developmental rate when $\mathrm{T}$ is $0^{\circ} \mathrm{C}, \mathrm{b}$ is slope of the regression line. Lower temperature threshold $\left(\mathrm{T}_{\min }\right)$ was estimated as the $\mathrm{x}$-intercept $(=-\mathrm{a} / \mathrm{b})$. The number of degree days (DD) or heat units needed for the development of each stage was estimated from the reciprocal of the fitted regression line $\left(b^{-1}\right)$ represented as thermal constant $(k)$.

The line fitting method proposed by Ikemoto and Takai (2000) was used as the second linear model which is expressed as

$$
D T=k+T_{\min } D,
$$

where, $\mathrm{D}$ is the duration of development (days), $\mathrm{T}$ is the temperature $\left({ }^{\circ} \mathrm{C}\right), \mathrm{k}$ is thermal constant and $\mathrm{T}_{\min }$ is the lower developmental threshold.

\section{Nonlinear models}

The nonlinear models describe the developmental rate over a wider range of temperature and provide estimates of the optimum threshold temperature $\left(\mathrm{T}_{\text {opt }}\right)$ and upper temperature threshold $\left(\mathrm{T}_{\max }\right)$. The developmental rate is maximum at $\mathrm{T}_{\text {opt }}$ while the development ceases at $\mathrm{T}_{\max }$. Lactin2 model (Lactin et al., 1995) that combines both sigmoid and exponential equations, similar 3-parameter Briere-1 model (Briere et al., 1999) and simplified $\beta$ type distribution function (Damos and Soultani, 2008) were fitted to assess the nonlinear relationship between developmental rate (1/ $\mathrm{D})$ and temperature $(\mathrm{T})$. All the three empirical nonlinear 
Table 1 : Mean number of days for development $( \pm \mathrm{SE})$ of immature stages of $N$. lugens at six constant temperatures.

\begin{tabular}{|c|c|c|c|c|c|c|c|c|c|}
\hline \multirow{2}{*}{$\begin{array}{l}\text { Temperature } \\
\left( \pm 1^{\circ} \mathrm{C}\right)\end{array}$} & \multirow[t]{2}{*}{$\mathrm{N}$} & \multirow[t]{2}{*}{ Egg } & \multicolumn{5}{|c|}{ Nymph } & \multirow[b]{2}{*}{ Totalnymph } & \multirow[b]{2}{*}{ Total immature } \\
\hline & & & I & II & III & $\mathrm{IV}$ & $\mathrm{V}$ & & \\
\hline 15 & 22 & $28.4 \pm 0.19 \mathrm{a}$ & $7.5 \pm 0.34 \mathrm{a}$ & $8.4 \pm 0.44 a$ & $9.3 \pm 0.45 \mathrm{a}$ & $10.9 \pm 0.38 \mathrm{a}$ & $9.9 \pm 0.42 \mathrm{a}$ & $46.0 \pm 1.06 \mathrm{a}$ & $74.4 \pm 1.10 \mathrm{a}$ \\
\hline 18 & 19 & $21.4 \pm 0.11 b$ & $6.0 \pm 0.13 b$ & $4.9 \pm 0.15 b$ & $5.2 \pm 0.16 \mathrm{~b}$ & $5.1 \pm 0.13 b$ & $5.1 \pm 0.14 b$ & $26.2 \pm 0.22 b$ & $47.6 \pm 0.25 b$ \\
\hline 20 & 16 & $15.6 \pm 0.13 c$ & $5.6 \pm 0.13 b c$ & $4.9 \pm 0.11 b$ & $5.1 \pm 0.06 \mathrm{~b}$ & $4.7 \pm 0.18 b$ & $4.4 \pm 0.16 b$ & $24.7 \pm 0.31 b$ & $40.3 \pm 0.36 c$ \\
\hline 25 & 38 & $12.0 \pm 0.00 \mathrm{~d}$ & $3.7 \pm 0.08 \mathrm{~d}$ & $3.0 \pm 0.04 \mathrm{~d}$ & $3.0 \pm 0.05 \mathrm{~d}$ & $2.7 \pm 0.07 \mathrm{c}$ & $2.8 \pm 0.10 \mathrm{c}$ & $15.1 \pm 0.10 \mathrm{~d}$ & $27.1 \pm 0.10 \mathrm{e}$ \\
\hline 30 & 26 & $9.0 \pm 0.00 \mathrm{f}$ & $3.2 \pm 0.08 \mathrm{~d}$ & $2.3 \pm 0.09 \mathrm{~d}$ & $2.5 \pm 0.10 \mathrm{~d}$ & $2.5 \pm 0.11 \mathrm{c}$ & $3.0 \pm 0.15 \mathrm{c}$ & $13.4 \pm 0.19 \mathrm{~d}$ & $22.4 \pm 0.19 \mathrm{f}$ \\
\hline 32 & 24 & $11.0 \pm 0.13 \mathrm{e}$ & $5.0 \pm 0.18 \mathrm{c}$ & $4.0 \pm 0.13 \mathrm{c}$ & $4.1 \pm 0.22 \mathrm{c}$ & $4.5 \pm 0.16 b$ & $4.6 \pm 0.18 b$ & $22.1 \pm 0.53 \mathrm{c}$ & $33.1 \pm 0.50 \mathrm{~d}$ \\
\hline $\mathrm{F}$ & & 5119.46 & 90.79 & 131.60 & 141.26 & 288.28 & 162.75 & 610.03 & 1496.47 \\
\hline df & & 5,139 & 5,139 & 5,139 & 5,139 & 5,139 & 5,139 & 5,139 & 5,139 \\
\hline$P$ & & $<0.0001$ & $<0.0001$ & $<0.0001$ & $<0.0001$ & $<0.0001$ & $<0.0001$ & $<0.0001$ & $<0.0001$ \\
\hline
\end{tabular}

Means within a column followed by the same letter are not significantly different $(P<0.05$ Tukey's HSD test).

forms differed in number of parameters to be estimated, inclusion of biologically meaningful parameters in the equation, model ability to estimate lower or optimum temperature thresholds and statistical properties of the estimators of parameters. In addition, a thermodynamic nonlinear Sharpe-Schoolfield-Ikemoto model (SSI model) that involves biochemical interpretation based on enzyme kinetics was used to estimate intrinsic optimum temperature for BPH (Shi et al., 2012).

Lactin-2 model(Lactin et al., 1995) is given by the equation

$$
\frac{1}{D}=e^{\rho \times T}-e^{\left[\rho \times T_{\max }-\left(\left(T_{\max }-T\right) \div \Delta\right)\right]}+\lambda
$$

where, $\mathrm{D}$ is mean developmental duration (in days), $\rho$ is the constant defining developmental rate at optimal temperature, $\Delta$ is the range over 'thermal breakdown' becomes the overriding influence, and $\lambda$ is a constant forcing the nonlinear curve to intercept with the $\mathrm{x}$-axis, thereby allowing an estimation of the lower developmental threshold. $\mathrm{T}_{\max }$ is thermal maximum (lethal temperature at which life process can no longer be maintained for a prolonged period).

The Briere-1 model (Briere et al., 1999) is given by the expression,

$$
r(T)=a T\left(T-T_{\min }\right) \sqrt{\left(T_{\max }-T\right)}
$$

where, $r$ is the developmental rate $\left(\right.$ day $\left.^{-1}\right), \mathrm{T}$ is temperature $\left({ }^{\circ} \mathrm{C}\right)$, and ' $\mathrm{a}$ ' is an empirical constant, $\mathrm{T}_{\text {min }}$ is lower developmental threshold and $\mathrm{T}_{\max }$ is upper developmental threshold.

The simplified $\beta$ type distribution function (Damos and Soultani, 2008) fitted to the data is given by the equation,

$$
\frac{1}{D}=k\left(\alpha-\frac{T}{10}\right)\left(\frac{T}{10}\right)^{\beta}
$$

where $\mathrm{k}, \alpha$ and $\beta$ are model parameters estimated by Marquardt's nonlinear least squares algorithm. $\mathrm{T}_{\max }$ and $\mathrm{T}_{\mathrm{opt}}$ could not be derived as parameters directly from this model. $\mathrm{T}_{\max }$ was estimated graphically from the rapid decline of the right descending branch (Damos and Soultani, 2008) and $\mathrm{T}_{\text {opt }}$ was derived using optimization (Prasad et al., 2012).

The nonlinear thermodynamic SSI model (Shi et al., 2012) is given by the expression

$$
r(T)=\frac{\rho_{\phi} \frac{T}{T_{\phi}} \exp \left[\frac{\Delta H_{A}}{R}\left(\frac{1}{T_{\phi}}-\frac{1}{T}\right)\right]}{1+\exp \left[\frac{\Delta H_{L}}{R}\left(\frac{1}{T_{L}}-\frac{1}{T}\right)\right]+\exp \left[\frac{\Delta H_{H}}{R}\left(\frac{1}{T_{H}}-\frac{1}{T}\right)\right]}
$$

where, $r$ represents developmental rate $(r)$ as a function of temperature, $\mathrm{T}$ (in absolute temperature, $\mathrm{K})(273.15 \mathrm{~K}=$ $\left.0^{\circ} \mathrm{C}\right), \mathrm{R}$ is the universal gas constant $\left(1.987 \mathrm{cal} \mathrm{deg}^{-1} \mathrm{~mol}^{-1}\right)$, $\mathrm{T}_{\mathrm{L}}, \mathrm{T}_{\mathrm{H}}$ and $\mathrm{T}_{\phi}$ represent absolute temperatures below $\left(\mathrm{T}_{\mathrm{L}}\right)$, above $\left(\mathrm{T}_{\mathrm{H}}\right)$ and an optimum temperature $\left(\mathrm{T}_{\phi}\right)$ at which an enzyme is 50 per cent active. $\Delta \mathrm{H}_{\mathrm{A}}, \Delta \mathrm{H}_{\mathrm{L}}$ and $\Delta \mathrm{H}_{\mathrm{H}}$ represent enthalpy changes, $\rho_{\phi}$ is the mean developmental rate at the intrinsic optimum temperature $\left(\mathrm{T}_{\phi}\right), \mathrm{T}_{\phi}$ is the intrinsic optimum temperature at which the probability of enzyme being in the active state is maximal $(\mathrm{K})$. 
Table 2 : Adult longevity (days) and sex ratio of $N$. lugens at constant temperatures.

\begin{tabular}{llll}
\hline Temperature $\left( \pm 1^{\circ} \mathrm{C}\right)$ & $\mathrm{n}$ & Adult longevity $($ Mean $\pm \mathrm{SE})$ & Sex ratio $(\mathrm{F}: \mathrm{M})$ \\
\hline 15 & 22 & $24.1 \pm 2.02 \mathrm{a}$ & $1.3: 1.0$ \\
18 & 19 & $18.8 \pm 2.23 \mathrm{ab}$ & $1.4: 1.0$ \\
20 & 16 & $19.0 \pm 2.09 \mathrm{ab}$ & $1.7: 1.0$ \\
25 & 38 & $13.9 \pm 0.96 \mathrm{bc}$ & $1.0: 1.0$ \\
30 & 26 & $16.6 \pm 0.85 \mathrm{~b}$ & $0.9: 1.0$ \\
32 & 24 & $9.9 \pm 0.69 \mathrm{c}$ & $0.5: 1.031 .8$ \\
$\mathrm{~F}$ & & 11.52 & \\
Df & & 5,161 & \\
$\mathrm{p}$ & & $<0.0001$ & \\
\hline
\end{tabular}

Means within a column followed by the same letter are not significantly different $(P<0.05$; Tukey's HSD test $)$; n, sample size; F, F statistic value; df, degrees of freedom; , p value of the statistical test.

Table 3 : Summary statistics for developmental duration of total immatures of $N$. lugens at constant temperatures.

\begin{tabular}{llll}
\hline Temperature $\left( \pm 1^{\circ} \mathrm{C}\right)$ & \multicolumn{3}{c}{ Percentile duration for total immature development (days) } \\
\cline { 2 - 4 } & $25^{\text {th }}$ percentile $(\mathrm{LL}, \mathrm{UL})$ & $50^{\text {th }}$ percentile $(\mathrm{LL}, \mathrm{UL})$ & $75^{\text {th }}$ percentile $(\mathrm{LL}, \mathrm{UL})$ \\
\hline 15 & $43(24,49)$ & $65(56,72)$ & $73(66,79)$ \\
18 & $14(6,38)$ & $40(19,41)$ & $44(41,55)$ \\
20 & $9(5,36)$ & $36(17,43)$ & $43(38,52)$ \\
25 & $23(9,25)$ & $26(24,28)$ & $31(28,34)$ \\
30 & $7(4,24)$ & $26(21,28)$ & $29(27,32)$ \\
32 & $9(5,12)$ & $23(11,29)$ & $33(29,35)$ \\
\hline
\end{tabular}

LL and UL are the lower and upper limits of the $95 \%$ confidence interval respectively.

\section{Statistical analysis}

The effect of temperature on the development of different stages of BPH was analysed following one-way analysis of variance (ANOVA) and means were compared using TukeyKramer honestly significant difference (HSD) test at 5 per cent level of significance using PROC GLM in SAS 9.2 (SAS Institute, 2009). Kaplan-Meier or product limit analysis of the survival data is carried out using PROC LIFE TEST (SAS Institute, 2009) to test statistical difference among survival curves and estimate median survival time at different constant temperatures.

Linear relationship between rate of development $(1 / D)$ and temperature $(\mathrm{T})$ was determined using thermal summation model (Campbell et al., 1974) and regression was performed with replicate data using PROC REG to obtain regression parameters $(a$ and $b$ ). Nonparametric Wilcoxon Signed Rank test was used to test two linear models for significant differences in the estimates of $\mathrm{T}_{\min }$ and thermal constants for different life stages of BPH.
PROC NLIN was performed to estimate parameters of nonlinear Lactin-2 model $\left(\lambda, \rho, \mathrm{T}_{\max } \lambda\right.$ and $\left.\Delta\right)$ and Briere-1 model $\left(a, \mathrm{~T}_{\min }\right.$ and $\left.\mathrm{T}_{\max }\right) \cdot \mathrm{T}_{\text {opt }}$ of the fitted models was estimated by using PROC OPTMODEL. Similarly, PROC NLIN was used to estimate parameters of simplified $\beta$ type distribution function $(k, \alpha$ and $\beta)$ and to derive $\mathrm{T}_{\text {opt }}$. Optim SSI function in SSI package version 2.7 in R software was used to estimate the SSI model parameters. Model performance evaluation of the four nonlinear models was made based on $R^{2}$ goodnessof-fit statistics.

\section{Field validation of phenology based degree day model}

The phenology based degree day model developed for $\mathrm{BPH}$ was validated with field data collected from Kampasagar area of Nalgonda district, Telangana State, India during wet season, 2015. The pest incidence was observed regularly in the field starting from 15 days after transplanting to know the first appearance of the macropterous adults of BPH which was considered as biofix for validation of phenology model. Further observations on different life stages of BPH 
Table 4 : Estimates of temperature thresholds for egg, nymphal and total immature development of $N$. lugens using linear and non-linear regression analysis

\begin{tabular}{|c|c|c|c|c|}
\hline Model & Parameters & Egg & Nymph & Egg to Adult \\
\hline \multirow[t]{5}{*}{ Campbell model } & $\mathrm{T}_{\min }$ & $8.1 \pm 0.5$ & $8.1 \pm 1.4$ & $8.1 \pm 0.8$ \\
\hline & $\mathrm{k}$ & $198.8 \pm 1.7$ & $275.5 \pm 6.7$ & $473.9 \pm 6.1$ \\
\hline & $\mathrm{R}^{2}$ & 0.9916 & 0.9347 & 0.9808 \\
\hline & df & 1,119 & 1,119 & 1,119 \\
\hline & $\mathrm{p}$ & $<0.0001$ & $<0.0001$ & $<0.0001$ \\
\hline \multirow[t]{5}{*}{ Ikemoto Takai model } & LDT & 8.3 & 9.5 & 8.8 \\
\hline & SET & 194.2 & 249.4 & 452.4 \\
\hline & $\mathrm{R}^{2}$ & 0.9860 & 0.9834 & 0.9946 \\
\hline & df & 2,3 & 2,3 & 2,3 \\
\hline & $\mathrm{p}$ & $<0.0001$ & $<0.0001$ & $<0.0001$ \\
\hline \multirow[t]{6}{*}{ Lactin -2} & $\mathrm{~T}_{\min }$ & 8.7 & 11.2 & 10.4 \\
\hline & $\mathrm{T}_{\mathrm{opt}}$ & 29.8 & 27.8 & 28.5 \\
\hline & $\mathrm{T}_{\max }$ & 35.0 & 35.0 & 35.0 \\
\hline & $\mathrm{R}^{2}$ & 0.977 & 0.918 & 0.954 \\
\hline & $\mathrm{df}$ & 3,3 & 3,3 & 3,3 \\
\hline & $\mathrm{p}$ & 0.00213 & 0.01385 & 0.00596 \\
\hline \multirow[t]{6}{*}{ Briere } & $\mathrm{T}_{\min }$ & 8.7 & 6.0 & 7.1 \\
\hline & $\mathrm{T}_{\text {opt }}$ & 29.0 & 28.7 & 28.8 \\
\hline & $\mathrm{T}_{\max }$ & 35.0 & 35.0 & 35.0 \\
\hline & $\mathrm{R}^{2}$ & 0.966 & 0.878 & 0.938 \\
\hline & df & 2,4 & 2,4 & 2,4 \\
\hline & $\mathrm{p}$ & 0.00051 & 0.00666 & 0.0017 \\
\hline \multirow[t]{5}{*}{ Simplified beta type function } & $\mathrm{T}_{\text {opt }}$ & 28.2 & 27.6 & 27.8 \\
\hline & $\mathrm{T}_{\max }$ & 35.1 & 35.0 & 35.0 \\
\hline & $\mathrm{R}^{2}$ & 0.912 & 0.950 & 0.959 \\
\hline & df & 2,4 & 2,4 & 2,4 \\
\hline & $\mathrm{p}$ & 0.00345 & 0.0011 & 0.00073 \\
\hline
\end{tabular}

$\mathrm{T}_{\min }$, lower temperature threshold; $\mathrm{T}_{\max }$, upper temperature threshold; $\mathrm{T}_{\text {opt }}$, optimal temperature threshold; $\mathrm{R}^{2}$, coefficient of determination; df, degrees of freedom; p, p value; LDT, lower developmental threshold; SET, sum of effective temperature; $\mathrm{k}$, thermal constant.

(nymphal instars, and adults) were recorded at weekly intervals on 10 hills. Daily maximum and minimum temperature data during the crop season along with estimated $\mathrm{T}_{\min }$ and $\mathrm{T}_{\max }$ were used to calculate the accumulated degree days (ADD) using single sine method with horizontal upper cut-off(http://www.crida.in:8080/naip/home.jsp). Expected starting stage of the BPH and ADD were compared with the observed stages in field for validation of the model.

\section{RESULTS AND DISCUSSION}

\section{Development and Survival}

Temperature significantly influenced the development of BPH (Table 1). Complete development of BPH from egg to adult emergence was observed at all temperatures i.e. 15 to $32^{\circ} \mathrm{C}$. In the temperature range of 15 $30^{\circ} \mathrm{C}$, developmental duration decreased with increase in 
Table 5 : Parameter estimates of non-linear thermodynamic SSI model fitted to the mean developmental rate for different stages of $N$. lugens.

\begin{tabular}{llll}
\hline Parameter & Egg & Nymph & Total \\
\hline$\rho_{\phi}\left(\right.$ day $\left.^{-1}\right)$ & 0.0778 & 0.0550 & 0.0324 \\
$\mathrm{H}_{\mathrm{A}}(\mathrm{cal} / \mathrm{mol})$ & 13302.7 & 14389.1 & 13841.0 \\
$\mathrm{H}_{\mathrm{L}}(\mathrm{cal} / \mathrm{mol})$ & -61021.7 & -72920.2 & -66648.5 \\
$\mathrm{H}_{\mathrm{H}}(\mathrm{cal} / \mathrm{mol})$ & 122526.8 & 145644.1 & 142036.6 \\
$\mathrm{~T}_{\mathrm{L}}\left({ }^{\circ} \mathrm{C}\right)$ & 8.3 & 9.5 & 8.8 \\
$\mathrm{~T}_{\phi}\left({ }^{\circ} \mathrm{C}\right)$ & 23.4 & 23.2 & 23.4 \\
$\mathrm{~T}_{\mathrm{H}}\left({ }^{\circ} \mathrm{C}\right)$ & 32.6 & 31.4 & 31.8 \\
$\chi^{2}$ & 0.0009 & 0.0009 & 0.0002 \\
$\mathrm{R}^{2}$ & 0.986 & 0.983 & 0.995 \\
LDT $\left({ }^{\circ} \mathrm{C}\right)$ & 8.3 & 9.5 & 8.8 \\
SET $(\mathrm{DD})$ & 194.2 & 249.4 & 452.4 \\
\hline
\end{tabular}

temperature for each stage of $\mathrm{BPH}$, but increased at $32^{\circ} \mathrm{C}$ indicating a nonlinear response at extreme temperatures. Developmental duration of egg was significantly higher at $15^{\circ} \mathrm{C}$ and lowest at $30^{\circ} \mathrm{C}$ with increased duration at $32^{\circ} \mathrm{C}$. Nymphal instars also showed similar trend of linear decrease of development duration with increasing temperature till $30^{\circ} \mathrm{C}$. At $35^{\circ} \mathrm{C}$, no egg hatching was observed from the eggs laid by 25 gravid females and first instar nymphs collected from greenhouse culture of BPH could not survive beyond one week. The Kaplan-Meier survival curves (Fig. 1) revealed that survival curves were statistically not different in pairwise comparisons in the intermediate range of temperatures $\left(18\right.$ to $\left.30^{\circ} \mathrm{C}\right)$ but survival curve was significantly different at the lowest temperature tested $\left(15^{\circ} \mathrm{C}\right)$. Adult longevity was significantly more at $15^{\circ} \mathrm{C}$ and it varied from 24.1 to 9.9 days with temperature range of 15 to $32^{\circ} \mathrm{C}$ respectively (Table 2). Sex ratio was $1: 1$ at $25^{\circ} \mathrm{C}$ whereas female bias was observed below $25^{\circ} \mathrm{C}$ and male bias at higher temperatures. The expected median durations from Kaplan-Meier analysis were

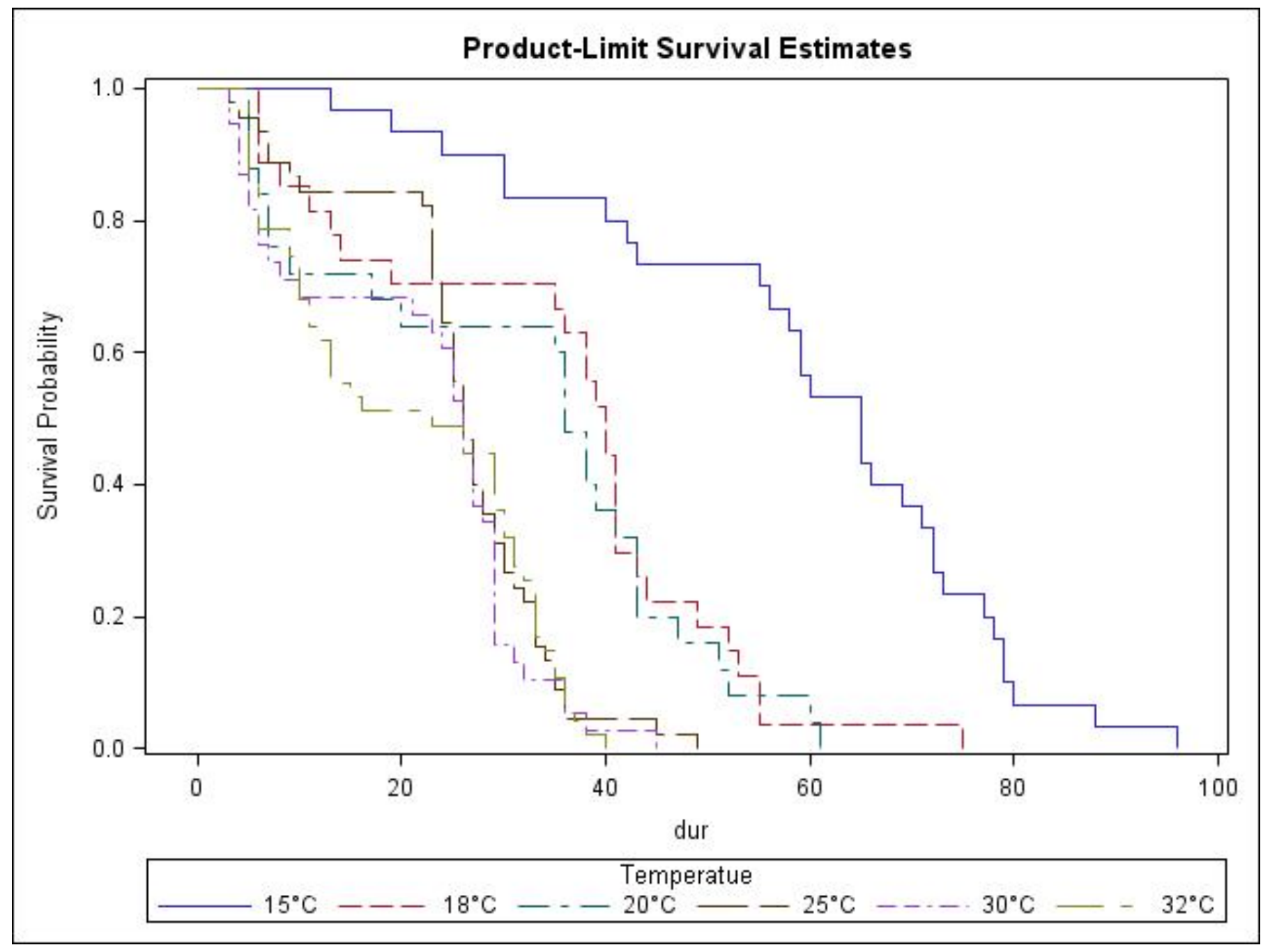

Fig.1 : Kaplan-Meier survival curves for the developmental duration of total immature of $N$. lugens at six constant temperatures. 

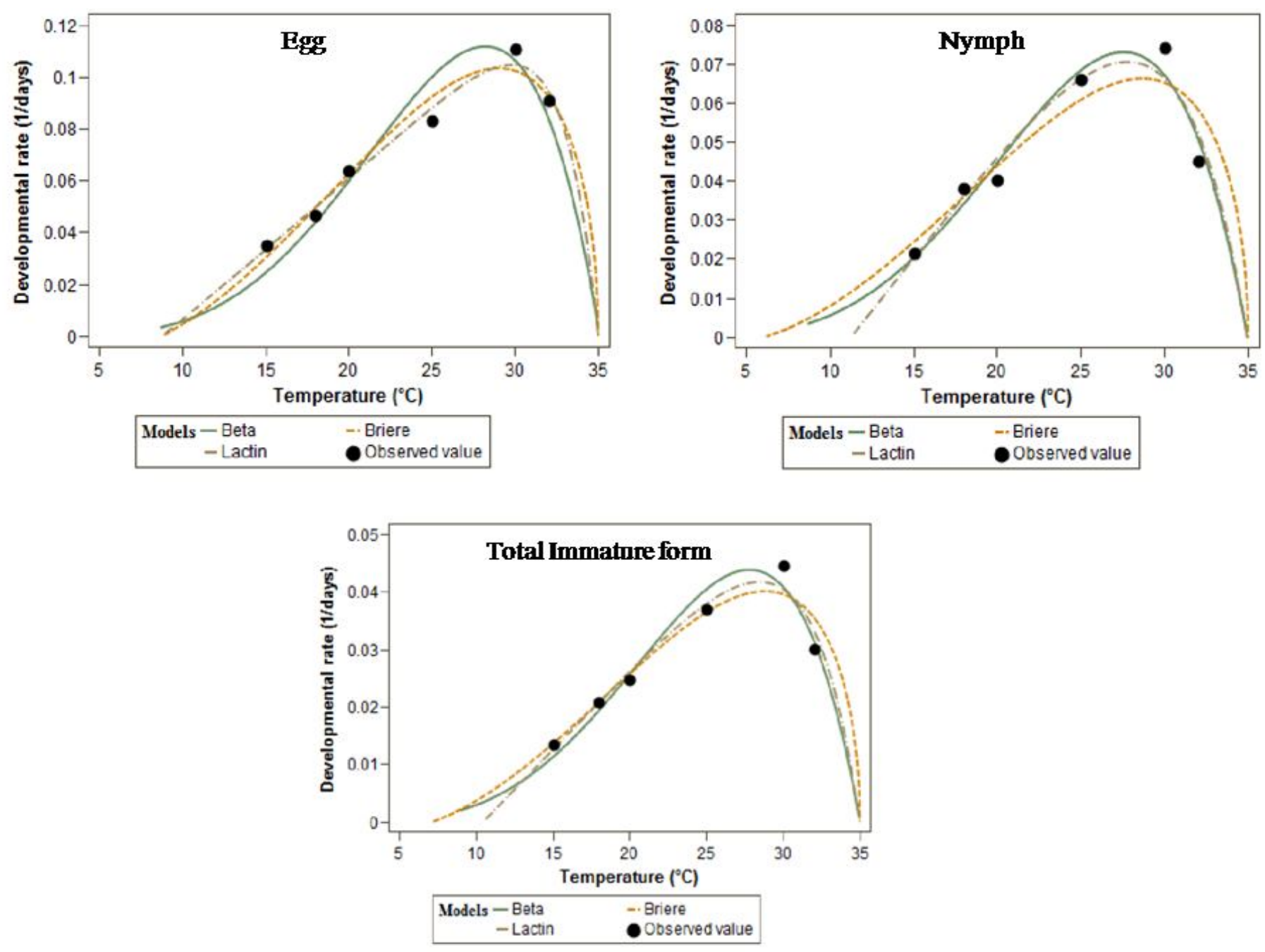

Fig.2 : Temperature-dependent developmental rate of BPH estimated by non-linear models.

$65,40,36,26,26$ and 23 days at $15,18,20,25,30$ and $32^{\circ} \mathrm{C}$, respectively (Table 3 ).

\section{Developmental thresholds and thermal constants}

Linear regression of developmental rate on temperature in the range of $15^{\circ} \mathrm{C}$ to $30^{\circ} \mathrm{C}$ was explained well for egg, nymph and total development of $\mathrm{BPH}\left(\mathrm{R}^{2}>0.93, \mathrm{P}\right.$ $<0.0001)$. The estimated $\mathrm{T}_{\min }$ for each life stage of BPH were $8.1^{\circ} \mathrm{C}$ (Table 4 ). The thermal constants, $\mathrm{k}$ for egg, nymph and total development were 198.8, 275.5 and 473.9 DD, respectively.

The nonlinear relationship between developmental rate and temperature for different life stages of $\mathrm{BPH}$ on rice was fitted well by all the three nonlinear models viz., Lactin2, Briere and $\beta$ type distribution function model (Fig. 2; Table 4). The estimated $\mathrm{T}_{\min }$ from Lactin-2 model were 8.7, 11.2 and $10.4^{\circ} \mathrm{C}$ for egg, nymph and total development of $\mathrm{BPH}$, respectively. However, they were estimated to be 8.7,
6.0 and $7.1^{\circ} \mathrm{C}$ from Briere model. The estimated $\mathrm{T}_{\text {max }}$ for all the life stages by Lactin-2, Briere and Simplified $\beta$ type function was $35.0^{\circ} \mathrm{C}$ except for egg from Simplified $\beta$ type function which was $35.1^{\circ} \mathrm{C}$. The $\mathrm{T}_{\text {opt }}$ for the total development were 28.5, 28.8 and 27.8 from Lactin-2, Briere and Simplified $\beta$ type function, respectively.

A thermodynamic nonlinear model (SSI) was used to estimate the intrinsic optimum temperature $\left(T_{\phi}\right)$ for development. Based on enzyme activity, other parameters such as mean developmental rate $\left(\rho_{\phi}\right)$ and enthalpy $\left(H_{A}, H_{L}\right.$ and $\mathrm{H}_{\mathrm{H}}$ ) were also estimated (Table 5). Lower developmental threshold values of $8.3,9.5$ and $8.8^{\circ} \mathrm{C}$, with sum of effective temperatures (SET) of 194.2, 249.4 and 452.4 degree days, were estimated for egg, nymph and total development, respectively. The intrinsic optimum temperature for the development of egg, nymph and total development was estimated at $23.4,23.2$ and $23.4^{\circ} \mathrm{C}$, respectively. The upper threshold temperatures $\left(\mathrm{T}_{\mathrm{H}}\right)$ for egg, nymph and total 
Table 6 : Field validation of phenology model based on accumulated degree-days (ADD)

\begin{tabular}{llrlr}
\hline Stage & \multicolumn{1}{c}{ Observed in the field } & \multicolumn{2}{c}{ Expected } & ADD \\
& Date of observation & ADD & Predicted starting date of the stage & 22.9 \\
\hline Adult & $10-09-2015$ & 22.9 & $10-09-2015$ & 237.4 \\
Nymph & $22-09-2015$ & 371.5 & $20-09-2015$ & 508 \\
Adult & $28-09-2015$ & 508 & $28-09-2015$ & 747.3 \\
Nymph & $11-10-2015$ & 794 & $09-10-2015$ & \\
\hline
\end{tabular}

development were estimated at $32.6,31.4$ and $31.8^{\circ} \mathrm{C}$, respectively.

\section{Validation of phenology model}

The estimated thermal constants and developmental thresholds were used in developing phenology model for predicting the timing of different stages of BPH in the field. The degree days required for completion of egg, nymph and total egg to adult development were 198.8, 275.5 and 473.9 , respectively. Degree days required for egg laying of emerged adults (pre-oviposition period) was estimated from three temperatures $\left(20,25\right.$ and $30^{\circ} \mathrm{C}$ ) (data not shown in table). Therefore, the total generation time was taken as 508.4 degree days. Under field conditions, the date on which the macropterous adults first appeared was treated as biofix date ( $10^{\text {th }}$ September, 2015). Timing of different life stages in the field were predicted by computing accumulated degree days (ADD) starting from the first date of appearance of adult in the field (biofix date). Field observations on prevalence of different life stages were recorded during the crop growth period to confirm the predicted pest occurrence stages. Adult emergence in the first generation was observed after accumulation of $508 \mathrm{ADD}$ (Table 6). Thus, the damaging stage of brown planthopper development was accurately predicted during wet season, 2015 which helps for timely and effective management of the pest.

Favourable temperature facilitates development, survival and reproduction of $N$. lugens (Krishnaiah et al., 2005). The developmental duration at each stage of BPH decreased with increase in temperature from 15 to $30^{\circ} \mathrm{C}$ (Table 1). A similar decrease in mean duration of egg and nymphal stages of BPH with increase in temperature from 15 to $30^{\circ} \mathrm{C}$ was reported by Krishnaiah et al., (2005). Durations of immature and longevity of mature forms were highest at $15^{\circ} \mathrm{C}$ with highest survival whereas, they were reduced with an increase in temperature from 15 to $30^{\circ} \mathrm{C}$ (Table 1). On the contrary at $32^{\circ} \mathrm{C}$, the duration of immature forms and longevity of mature forms was increased indicating nonlinear response at high and low temperatures (Wagner et al., 1984). The per cent survival of BPH was highest at $15^{\circ} \mathrm{C}$ and decreased with increase in temperature (Fig. 1; Table 3). Average rice field temperatures of more than $31^{\circ} \mathrm{C}$ would have obvious inhibitory effects on the survival and fecundity of BPH (Yu and Wu, 1992).

The linear degree day model estimates thermal constant and lower developmental threshold for each stage of the pest while the nonlinear model estimates optimum and maximum developmental thresholds. The relationship between temperature and developmental rate typically increases from a lower developmental threshold until optimum developmental threshold temperature, at which point it rapidly declines (Lactin et al., 1995). The estimated $\mathrm{T}_{\text {min }}$ for each life stage of BPH were $8.1^{\circ} \mathrm{C}$ from Campbell equation whereas these values were $8.3,9.5$ and $8.8^{\circ} \mathrm{C}$ for egg, nymph and total immature forms, respectively from Ikemoto and Takai linear model (Table 4). The thermal constants, $\mathrm{k}$ for egg, nymph and total development were 198.8, 275.5 and 473.9 DD, respectively from Campbell equation. A comparative analysis of the published datasets indicated that lower threshold value obtained in this study $\left(8.1^{\circ} \mathrm{C}\right)$ was close to the value reported by Krishnaiah et al., (2005).

Nonlinear models were applied well to the data and estimated $\mathrm{T}_{\text {min }}$ to be $8.7,11.2$ and $10.4^{\circ} \mathrm{C}$ (Lactin 2 model) and 8.7, 6.0 and $7.1^{\circ} \mathrm{C}$ (Briere model) for egg, nymph and total immature form development, respectively (Table 4). The estimated $\mathrm{T}_{\min }$ through the nonlinear models showed subtle differences in comparison to the values obtained by linear regression. This difference is due to the fact that the linear regression uses only the linear part of the points to calculate $\mathrm{T}_{\min }$, whereas nonlinear models also uses the observed points above the $\mathrm{T}_{\text {opt. }}$ The estimated sum of effective temperatures (SET) were 194.2, 249.4 and 452.4 degree days, for egg, nymph and total immature form development respectively from reduced major axis (Ikemoto and Takai, 2000) method. The estimated upper temperature threshold $\mathrm{T}_{\max }$ for all the life stages by Lactin-2, Briere and Simplified beta function was $35.0^{\circ} \mathrm{C}$ except for egg from simplified beta function which was $35.1^{\circ} \mathrm{C}$. The $\mathrm{T}_{\text {opt }}$ for the total development were $28.5,28.8$ and $27.8^{\circ} \mathrm{C}$ from Lactin-2, Briere and Beta 
function respectively. All the nonlinear models performed well based on the coefficient of determination, $\mathrm{R}^{2}$ as a goodness-of-fit criterion. Lactin 2 was relatively better fit than Briere and Simplified beta type function for egg while Simplified beta type function performed better for nymph and total immature form development. Thermal constants and lower temperature thresholds of life stages of BPH were compared with the earlier published data.

A thermodynamic nonlinear model (SSI) was used to estimate the intrinsic optimum temperature $\left(T_{\phi}\right)$ for development which can be used as an indicator for classifying phylogenetic relatedness (Ikemoto, 2005). The intrinsic optimum temperature and upper threshold temperatures $\left(\mathrm{T}_{\mathrm{H}}\right)$ for the development of egg, nymph and total immature form were estimated at $23.4,23.2,23.4^{\circ} \mathrm{C}$ and $32.6,31.4$, $31.8^{\circ} \mathrm{C}$, respectively (Table 5 ). $\mathrm{T}_{\mathrm{H}}$ is the most favourable temperature to the pest for its distribution and adaptation to the thermal environment.

Bioclimatic thresholds and thermal constants were used to develop pest phenology model (Sreedevi et al., 2013) to predict the timing of damaging life stages in the field for population dynamics and distribution of species (Safranyik et al., 2010). In our study, we developed phenology model based on linear Campbell model and predicted timing of different life stages in the field by computing accumulated degree days (ADD) starting from the first date of appearance of adult in the field (biofix date). Field observations on prevalence of different life stages were recorded during the crop growth period to confirm the predicted pest occurrence stages. The damaging nymphal stage was observed for timely and effective management of the pest. The predictive capacity of these phenology models enables to provide timely management of the pest and thus minimize crop loss leading to reduction in cost of cultivation.

\section{CONCLUSIONS}

Temperature significantly influenced the development and survival of BPH and it completed its development from egg to adult stage at constant temperatures ranging from 15 to $32^{\circ} \mathrm{C}$. Linear and nonlinear models fitted to describe developmental rates of life stages as a function of temperature, gave estimates of thermal constants and bioclimatic thresholds (lower, optimum and upper temperature thresholds) which were used in developing temperature dependent phenology models. These models enabled to predict the timing of different life stages of BPH in the field by computing accumulated degree days (ADD) starting from the first date of appearance of adult in the field (biofix date). Thus, prediction of the second generation of
BPH development was accurately done during wet season, 2015 for timely and effective management of the pest.

\section{ACKNOWLEDGMENTS}

The authors are grateful to ICAR - National Agricultural Innovative Project (NAIP C2046) for providing funds and facilities to carry out the work. We profusely thank Feng Ge and Peijian Shi for providing the Optim SSI package in R-software. We are also grateful to TM Manjunath, S Lingappa and NH Rao for their valuable suggestions.

\section{REFERENCES}

Briere, J.F., Pracros, P., Roux, A.Y.L. and Pierre, J.S. (1999). A novel rate model of temperature dependent development for arthropods. Environ. Entomol., 28: 22-29.

Campbell, A., Frazer, B.D., Gilbert, N., Gutierrez, A.P. and Mackauer, M. (1974). Temperature requirements of some aphids and their parasites. J. Appl. Ecol., 11:431438.

Catindig, G.S., Arida, Baehaki, S.E., Bentur, J.S., Cuong, L.Q., Norowi, M., Rattanakarn, W., Sriratanasak, W., Xia, J. and Lu, Z. (2009). Situation of planthoppers in Asia. In: K.L. Heong, B. Hardy(Eds.), Planthoppers: New Threats to the Sustainability of Intensive Rice Production Systems in Asia, Int. Rice Res. Inst, Los Banos, Philippines, pp. 191-220.

Damos, P.T. and Savopoulou-Soultani, M.S. (2008). Temperature-dependent bionomics and modeling of Anarsia lineatella (Lepidoptera: Gelechiidae) in the laboratory. J. Econ. Entomol., 101: 1557-1567.

Fand, B.B., Sul, N.T., Bal, S.K. and Minhas, P.S. (2015). Temperature impacts the development and survival of common cutworm (Spodoptera litura): Simulation and visualization of potential population growth in India under warmer temperatures through life cycle modelling and spatial mapping. PLOS ONE 10(4): e0124682. doi:10.1371/journal.pone.0124682.

http://www.crida.in:8080/naip/home.jsp.

Ikemoto., T. (2005). Intrinsic optimum temperature for development of insects and mites. Environ. Entomol., 34: 1377-1387.

Ikemoto, T. and Takai, K. (2000). Anew linearized formula for the law of total effective temperature and the evaluation of line-fitting methods with both variables subject to error. Environ. Entomol., 29: 671-682.

Krishnaiah, N.V. and Jhansi Lakshmi, V. (2012). Rice brown planthopper migration in India and its relevance to Punjab. J. Insect Sci., 25: 231-236. 
Krishnaiah, N.V., Rama Prasad, A.S., Raghavendra Rao, C., Pasalu, I.C., Jhansi Lakshmi, V., Lakshmi Narayanamma, V. and Lingaiah, T. (2005). Effect of constant and variable temperatures on biological parameters of rice brown planthopper, Nilaparvata lugens (Stål). Indian J. Plant Prot., 33:181-187.

Lactin, D.J., Holliday, N.J., Johnson, D.L. and Craigen, R. (1995). Improved rate model of temperature-dependent development by arthropods. Environ. Entomol., 24: 68-75.

Lu, Z.X., Yu, X.P., Chen, J.M., Zheng, X. S. and Zhang, Z.T. (1999). The tolerance differences of brown planthopper biotypes to adverse environmental factors. Acta Agric. Zhejiangensis., 11: 301-305.

Prasad, Y.G., Prabhakar, M., Sreedevi, G., Ramachandra Rao, G. and Venkateswarlu, B. (2012). Effect of temperature on development, survival and reproduction of the mealybug, Phenacoccus solenopsis Tinsley(Hemiptera: Pseudococcidae) on cotton. Crop Prot., 39: 81-88.

Rosenberg, L. J. and Magor, J. I. (1987). Predicting windborne displacements of the brown planthopper, Nilaparvata lugens from synoptic weather data. 1. Long-distance displacements in the north-east monsoon.J. Anim. Ecol., 56: $39-51$.

Safranyik, L., Carroll, A.L., Regniere, J., Langor, D.W., Riel, W.G., Shore, T.L., Peter, B., Cooke, B.J., Nealis, V.G. and
Taylor, S.W. (2010). Potential for range expansion of mountain pine beetle into the boreal forest of North America. Can. Entomol., 142: 415-442.

SAS Institute. (2009). PROC user's manual, version 9.2 ed. SAS Institute, Cary, NC.

Sharpe, P.J.H. and De Michele, D. W. (1977). Reaction kinetics of poikilotherm development. J. Theor. Biol., 66: 649671.

Shi, P., Li, B.L. and Ge, F. (2012). Intrinsic optimum temperature of the diamondback moth and its ecological meaning. Environ. Entomol., 41: 714-722.

Sreedevi, G., Prasad,Y.G., Prabhakar,M., Ramachandra Rao, G., Vennila, S. and Venkateswarlu, B. (2013). Bioclimatic Thresholds, Thermal Constants and Survival of Mealybug, Phenacoccus solenopsis (Hemiptera: Pseudococcidae) in Response to Constant Temperatures on hibiscus. PLoS ONE 8(9): e75636. doi:10.1371/ journal.pone.0075636.

Wagner, T.L., Wu, H.I., Sharpe, P.J.H., Schoolfield, R.M. and Coulson, R.N. (1984). Modelling insect developmental rate: literature review and application of a biophysical model. Ann. Entomol. Soc. Am., 77: 208-225.

Yu, X. and Wu, G. (1992). Effect of high temperatures on the survival and fecundity of brown planthopper (BPH) Nilaparvata lugens (Stål) IRRN., 17: 2. 